\title{
Sarcodon Mushrooms: Biologically Active Metabolites
}

\author{
Maria Carla Marcotullio \\ University of Perugia \\ Italy
}

\section{Introduction}

Thelephorales Corn ex. Oberw. belong to the Agaricomycetes (Basidiomycota, Fungi) and comprise more than 177 species (Kirk et al., 2008) that are classified into two families: the Bankeraceae Donk (mostly with colourless basidiospores) and the Thelephoraceae Chevall. (mostly with brown to yellowish basidiospores) (Yorou \& Agerer, 2007). Bankeraceae are characterized by a typical fenugreek odour, with pileate and stipitate fruit bodies, hydnoid to spinose hymenophores with brown and lobed as well as colourless and evenly ornamented basidiospores. Bankeraceae comprise 5 distinct genera: Bankera Coker \& Beers ex Pouzar, Hydnellum P. Karsten, Phellodon P. Karsten, Sarcodon Quél. ex P. Karst and Boletopsis Fayod.

The name Sarcodon was proposed by Quélet in 1878, but as any binomial was formed, the name was established as a genus only later by Karsten (Banker, 1913).

The name, derived from the ancient greek stems $s a r c o=$ flesh and odon=tooth, is due to the presence of the spines that look like teeth on the hymenophore. For this reason Sarcodon species are colloquial called "tooth fungi" (Fig. 1).

The genus comprises more than 72 species, most of which are not edible, due to the bitter taste. Among these species only few have been phytochemically and biologically studied: S. aspratus (syn S. imbricatus), S. cyrneus, S. glaucopus, S. leucopus, S. laevigetum (syn. S. laevigatus) and S. scabrosus.

Phytochemical studies were aimed to study either the composition of different extracts or to isolate new metabolites and to evaluate biological activity of extracts and isolated compounds.

\section{Phytochemical studies on Sarcodon spp}

\subsection{Sarcodon aspratus syn $\mathrm{S}$. imbricatus}

Sarcodon imbricatus (L.) P. Karst. is the current name used for S. aspratus (Berk.) even though several synonyms are used for this mushroom (see Index Fungorum: www.indexfungorum.org). It is commonly known as the shingled hedgehog or scaly hedgehog. The mushroom has a large, brownish cap with large brown scales and may reach $30 \mathrm{~cm}$ in diameter. On the underside it sports greyish brittle teeth instead of gills, and has white flesh. 


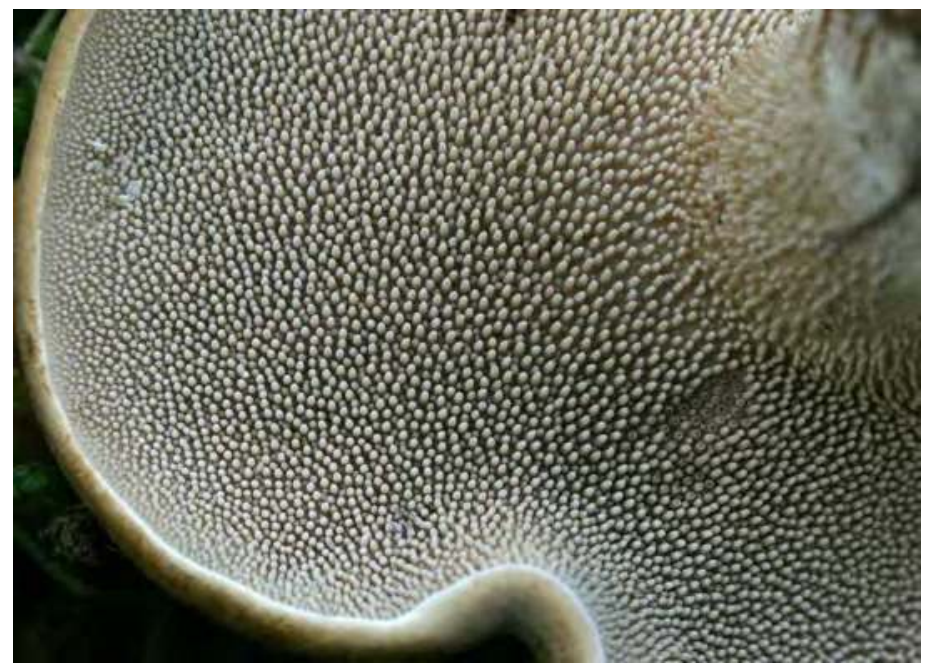

Fig. 1. Sarcodon imbricatus (L.: Fr.) Karsten hymenophore

The fungus can be bitter, although this is less apparent in younger specimens. Submerging the mushrooms in boiling water will remove this. It can be pickled or dried and used as flavouring. In Bulgaria it is collected, dried and finely ground to be used as an aromatic mushroom flour. It is reported as edible, but of poor quality in the United States by some sources but as deliciously edible by others. In China Sarcodon aspratus, also known as "black tiger's paw", is a popular natural edible mushroom. It is used for lowering cholesterol level, muscles relaxation and blood circulation. Its special musky aroma enhances the taste in meat's dishes, especially hams (S.K. Kim, 2006), and particularly brings out the sweet flavour when making a clear soup out of it.

Several papers have been published regarding the use of $S$. aspratus for manufacturing foods and beverages (e.g. Hwang \& Na, 2009a, 2009b; B.C. Kim et al., 2008, 2009; Jang, 2008; Wang \& Wang, 2008; J.K. Kim, 2007).

\subsubsection{Phytochemistry of Sarcodon imbricatus}

In view of its use as a food, the phytochemical composition of S. imbricatus has been studied.

Proximate constituents (moisture, fat, crude protein, ash and carbohydrates) of this mushroom have been reported (Barros et al., 2007a). On the basis of the proximate analysis, it can be calculated that a portion of $100 \mathrm{~g}$ of this mushroom provides, on average, $24 \mathrm{kcal}$ $(100 \mathrm{~kJ})$. The analysis of fatty acid composition allowed to determine 15 fatty acids.

Unsaturated fatty acids (MUFA, monounsaturated fatty acids, 46\%, PUFA, polyunsaturated fatty acids, 36\%) were predominant over SFA (saturated fatty acids, 18\%). Methanolic extract of S. imbricatus showed the presence $(0.5 \%)$ of total polyphenols, expressed as $g$ of gallic acid /100 g dry weight that justify the radical scavenging activity (DPPH) (Marcotullio et al., 2008). On the other hand the amounts of ascorbic acid, $\beta$-carotene and lycopene found in the mushroom were very low (Barros et al., 2007b). Sterol fraction was 


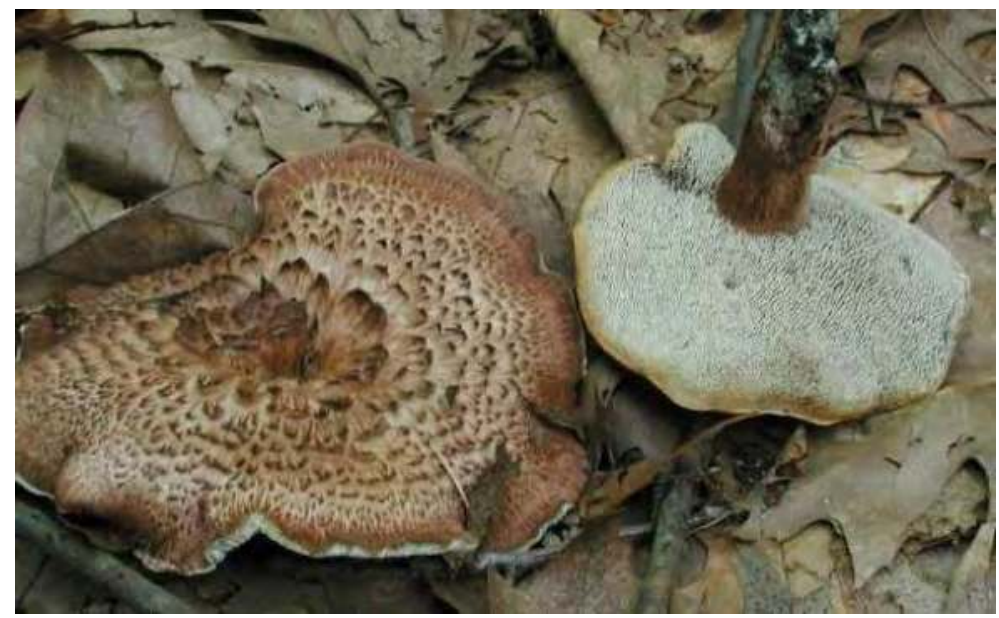

Fig. 2. Sarcodon imbricatus (L.: Fr.) Karsten

studied by several research groups. In addition to ergosterol, several other ergostane and cholestane compounds have been isolated (Huang et al., 2002; Ueno et al., 1999; Marcotullio et al., 2008). Particularly interesting is the presence in the methanolic extract of S. imbricatus of ergosterol peroxide (or 3- $\beta$-hydroxy-5a,8a-epidioxyergosta-6,22-diene) that shows a plethora of biological activities, such as antileukemic and anticancer (Kobori et al., 2006), apoptotic-inducing (Takei et al., 2005), and anti-inflammatory (Kobori et al., 2007). It is interesting to note that processing and cooking practices determine a lowering of nutrients concentrations and of antioxidant activity (Barros et al., 2007c).

Other interesting metabolites isolated and identified from S. aspratus are polysaccharides. Han and coworkers isolated a water soluble polysaccharide (HCP) with molecular mass of $6.7 \times 105 \mathrm{Da}$ (Han et al., 2011). HCP resulted to be a linear glucan with a backbone structure of $(1 \rightarrow 6)$-linked- $\alpha$-glupyranosyl residues. Another polysaccharide (HBP) with a molecular weight of $4.3 \times 105 \mathrm{Da}$ was isolated by the same author in 2010. Even in this case the backbone structure was constituted by $(1 \rightarrow 6)$-linked- $\alpha$-glupyranosyl residues, which occasionally branched at O-3 position (Han et al., 2010).

Other constituents isolated from S. aspratus were ceramide compounds (Yaoita et al., 2002).

\subsection{Sarcodon cyrneus Maas Gest}

Sarcodon cyrneus, according Myco Bank (www.mycobank.org), has a "pileus up to $65 \mathrm{~mm}$ across, planoconvex to somewhat depressed in centre, finely tomentose at margin, becoming felted farther back, or tomentum collapsed to form smooth and shiny pellicle. Stipe 15-30 x 6-15 mm, broader when fused, equal or somewhat enlarged below, with abruptly pointed base, straight to curved, tomentose, in places glabrescent, pale grey-brown, darkening with age and becoming more or less concolorous with, pileus, at extreme base with yellowish grey mycelium. Spines up to $3 \mathrm{~mm}$ long, 0.1-0.3 $\mathrm{mm}$ broad, long decurrent, often almost reaching base of stipe, crowded, subulate, first whitish, becoming purplish brown. Context pallid (whitish suffused with pinkish when fresh, according to the collector), not greenish in base of stipe" (Fig. 3). The taste is bitter and the mushroom is not edible. 


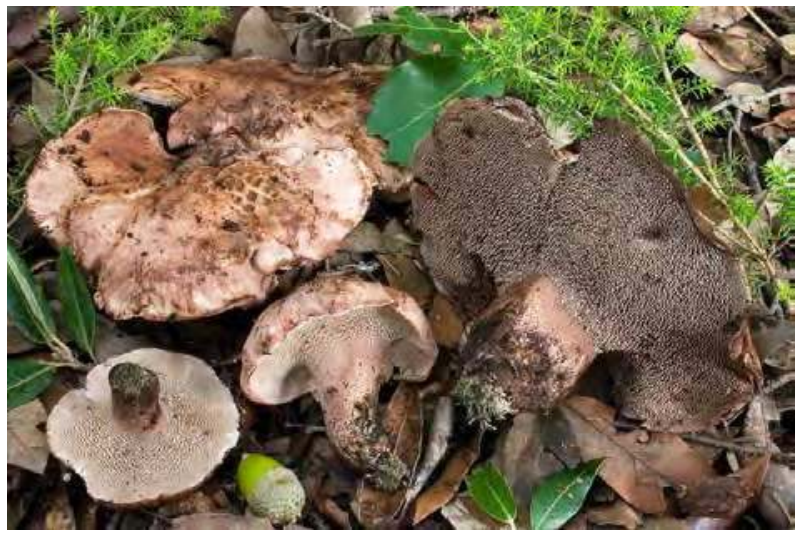

Fig. 3. Sarcodon cyrneus Maas Geest.

\subsubsection{Phytochemistry of Sarcodon cyrneus}

In the literature only two papers regarding the secondary metabolites isolated from $S$. cyrneus have been reported (Marcotullio et al., 2006b; Marcotullio et al., 2007) and they deals with the structural identification of five cyathane diterpenes. These compounds were named cyrneine A-D (1-4) (Fig. 4) and glaucopine C (7) (Fig. 6).

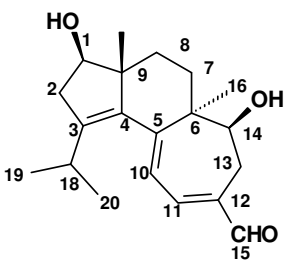

1

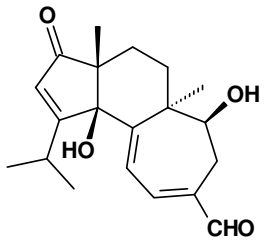

2

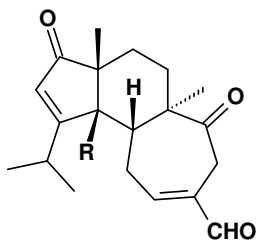

$3 \mathrm{R}=\mathrm{H}$ $4 \mathrm{R}=\mathrm{OH}$

Fig. 4. Structures of cyrneines

\subsection{Sarcodon glaucopus Maas Geest. \& Nannf.}

According MycoBank (www.mycobank.org) the mushroom has a "pileus up to $110 \mathrm{~mm}$ across, plano-convex to somewhat depressed; at first tomentose, then matted, forming a cuticle which breaks up into scales near margin, into areoles in centre; scales adhering to appressed, yellow-brown with vinaceous shade or pale to dark purplish brown, occasionally locally violet-grey (giving a peculiar leaden grey impression), at times very dark brown in centre, contrasting with dingy yellowish ground colour, not infrequently covered with minute yellowish dots of excreted matter when dried. Stipe $27-75 \times 10-40 \mathrm{~mm}$, cylindrical, tapering below or somewhat broadened below, tomentose, fibrillose, covered with adnate fibrillose squamules or partly matted, dingy whitish, soon pinkish brown to purplish brown above, grey-green below, with pointed, whitish base. Spines up to $5 \mathrm{~mm}$ long, 0.1-0.2 $\mathrm{mm}$ broad, whitish, finally purplish brown" (Fig. 5). The taste is bitter and the mushroom is not edible. 


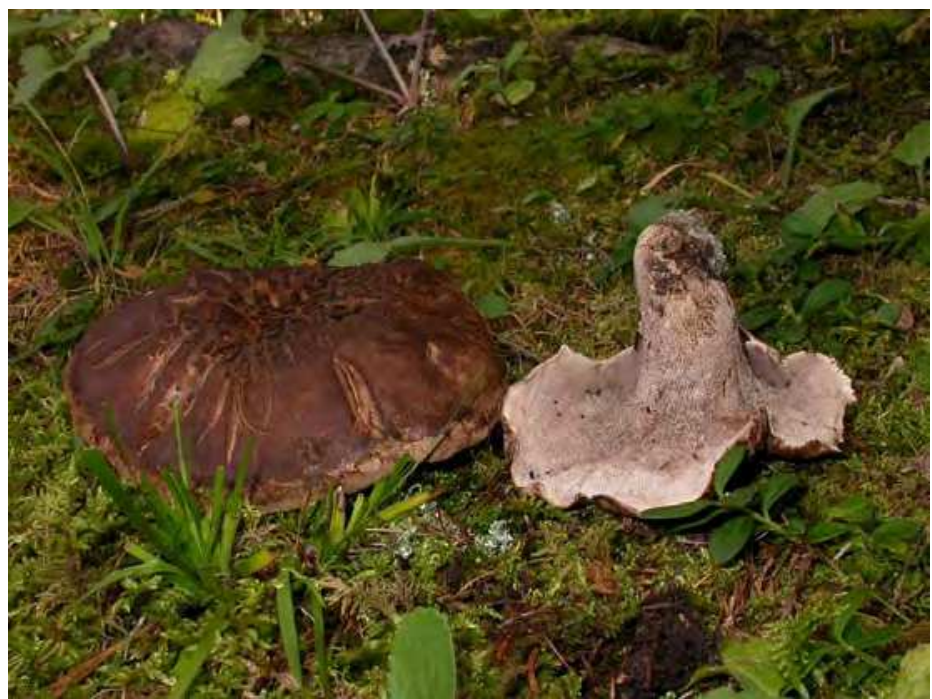

Fig. 5. Sarcodon glaucopus Maas Geest. \& Nannf.

\subsubsection{Phytochemistry of Sarcodon galucopus}

No phytochemical studies regarding proximate composition have been reported for $S$. glaucopus. In the literature there are only two studies on the secondary metabolites of $S$. glaucopus, and they deal with the isolation and structure elucidation of three cyathane diterpenes named glaucopine A (5), glaucopine B (6) (Curini et al., 2005) and glaucopine C (7) (Marcotullio et al., 2006a) (Fig. 6).

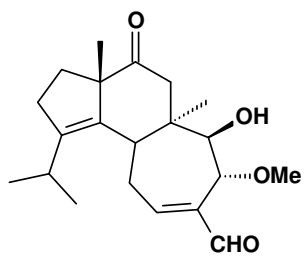

5

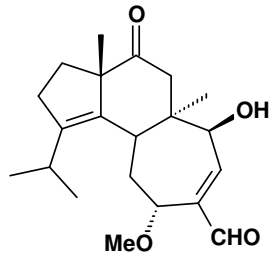

6

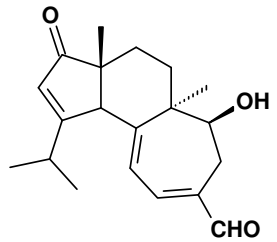

7

Fig. 6. Structures of glaucopines

\subsection{Sarcodon laevigatus (Sw.) P. Karst.}

Index Fungorum (www.indexfungorum.org) reports for S. laevigatus (syn. S. leucopus, often the term S. laevigatum is used instead of S. laevigatus). A description of Sarcodon leucopus (Pers.) Maas Geest. \& Nannf. has been reported in MycoBank: “Pileus up to ca. $200 \mathrm{~mm}$ across, planoconvex or slightly depressed, without concentric or radiate markings, at first finely felted; felt collapsed to form smooth, more or less shiny, innate-scaly cuticle, the latter subsequently radiately rimose near margin, breaking up into areoles in centre, here with scales somewhat more pronounced and tips sometimes slightly raised; pale purplish brown 
on yellowish drab ground colour or a rich purplish brown to dark brown. Stipe 40-80 x 20-60 $\mathrm{mm}$, cylindrical to ventricose, finely tomentose, later with smooth or innate-scaly cuticle, concolorous with pileus or paler, whitish below, after some time with green spots (always?). Spines up to c. $15 \times 1 \mathrm{~mm}$, whitish, finally purplish brown. Context up to $40 \mathrm{~mm}$ thick near centre of pileus, whitish, suffused with purplish brown to violet tints, after some time pale greenish. Odour commonly experienced as disagreeable. Taste bitter after some time".

\subsubsection{Phytochemistry of Sarcodon laevigatus or/and S. leucopus}

In the literature no references to $S$. laevigatus have been reported, while it is possible to find two papers referring to $S$. laevigatum and to $S$. laevigetum. The first one reports the isolation and the structure identification of three p-terphenyls (8-10), of which 8 (named sarcodan) was a new compound (Ma et al., 2006). The second report is a Patent and deals with the preparation of compound 9 (named B1-V) by extraction from S. laevigetum (Ma, 2009).

On the other hand, Tringali and coworkers (Tringali et al., 1987) reported the isolation and structure identification of several p-terphenyls from Sarcodon leucopus.

The first two isolated compounds were 10 and 11. (Fig. 8)

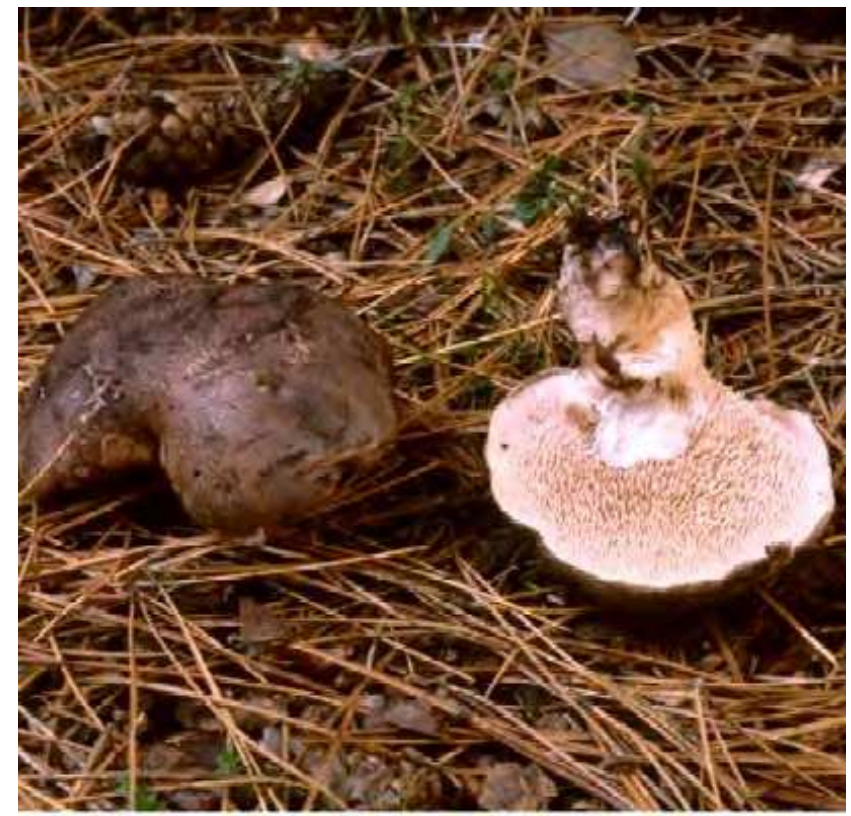

Fig. 7. Sarcodon leucopus (Pers.) Maas Geest. \& Nannf.

It is evident from these reports how the correct identification of the species is important for preventing mistakes in the identification of new secondary metabolites.

Later, the same research group isolated other nitrogen-containing p-terphenyl derivatives that they named sarcodonins. The first to be isolated was 12 in 2000 (Geraci et al., 2000) and other six related compounds (13-18) were isolated in 2004 (Cali et al., 2004) (Fig. 9). 
<smiles>CC(=O)Oc1ccc(-c2c(OC(C)=O)c(OC(C)=O)c3c(oc4cc(O)c(O)cc43)c2O)cc1</smiles>

8<smiles>CC(=O)Oc1c(OC(C)=O)c(-c2ccc(O)c(O)c2)c(O)c(O)c1-c1ccc(O)cc1</smiles><smiles>CC(=O)Oc1c(-c2ccc(O)cc2)c(O)c2oc3cc(O)c(O)cc3c2c1OC(C)=O</smiles>

9<smiles>CC(=O)Oc1ccc(-c2c(O)c(O)c(-c3ccc(O)c(O)c3)c(OC(C)=O)c2OC(C)=O)cc1</smiles>

10

11

Fig. 8. Structures of $p$-terphenyls isolated from S. laevigatum<smiles>[R6]Oc1ccc(-c2c(O[R20])c(O)c(-c3ccc4c(c3)O[C@]3(C(C)CC)O[N+]4(O)C(O)=C(C(C)CC)N(OC(C)=O)C3=O)c(OC(C)=O)c2OC(C)(C)C)cc1</smiles>

$12 \mathbf{R}_{1}=\mathrm{Ac} ; \mathrm{R}_{2}=\mathrm{H} ; \quad \mathrm{R}_{3}=\mathrm{H} ; \quad \mathrm{R}_{4}=\mathrm{H}$

$13 \quad R_{1}=H ; R_{2}=H ; \quad R_{3}=H ; \quad R_{4}=H$

$14 R_{1}=H ; R_{2}=A c ; R_{3}=H ; R_{4}=H$

$15 R_{1}=A c ; R_{2}=H ; R_{3}=A c ; R_{4}=A c$<smiles>[R6]Oc1ccc(-c2c(O[R20])c(O)c(-c3ccc4c(c3)O[C@]3(C(C)CC)ON4C(O)=C(C(C)CC)N(OC(C)=O)C3=O)c(OC(C)=O)c2OC(C)=O)cc1</smiles>

$16 R_{1}=A c ; R_{2}=H ; \quad R_{3}=H ; \quad R_{4}=H$

$17 \quad R_{1}=H ; R_{2}=H ; R_{3}=H ; \quad R_{4}=H$

$18 R_{1}=H ; R_{2}=A c ; R_{3}=H ; \quad R_{4}=H$

Fig. 9. Structures of sarcodonins isolated from S. leucopus

Compounds 13-15 were named sarcodonin $\alpha, \beta$, and $\gamma$, respectively, while compounds 16-18 epi-sarcodonin, epi-sarcodonin $\alpha$ and $\beta$, respectively. Cali et al., (2004) from the same mushroom isolated oxidated sarcodonins and named them sarcoviolin (19) and epi-sarcoviolin (20) (Fig. 10).

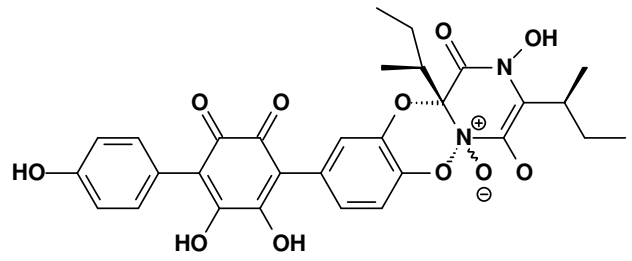

Fig. 10. Structures of sarcoviolins 
Recently the structures of sarcodonins and sarcoviolins have been revised by synthesis, and the new structure for sarcodonin 12 is reported in Fig. 11 (Lin et al., 2011).

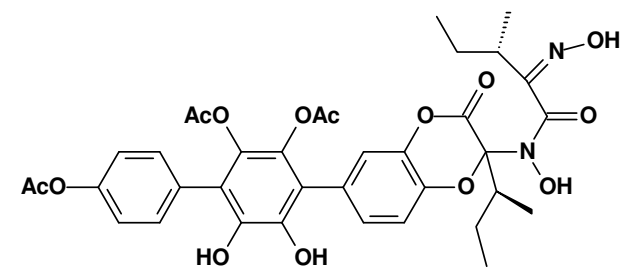

Fig. 11. Revised structure proposed for sarcodonin 12

It is very interesting to notice that screening the literature with the term "sarcodonin" different structures with the same name have been reported, as we will see checking the compounds isolated from S. scabrosus.

\subsection{Sarcodon scabrosus (Fr.) P. Karst.}

Myco Bank describes S. scabrosus "with pileus up to $120 \mathrm{~mm}$ across (fresh), plano-convex, more or less deeply depressed in the centre, coarsely scaly, the scales erect in the centre, decumbent farther outwards, adnate and woolly near the margin, brown in various shades (brick-colour, fulvous, ferruginous, bay) on a fairly pale yellow-brown ground, in some specimens passing into a delicate lilac at the margin, with age becoming very dark purplish brown, and the scale-tips even blackish, somewhat shiny when dried. Stipe 20$120 \times 10-60 \mathrm{~mm}$ (fresh), tapering downwards, usually with pointed base, felted to subfibrillose, pinkish brown to brick-colour, becoming concolorous with the pileus, the lower part or the base grey-green, when young covered with white mycelium. Spines up to $5 \mathrm{~mm}$ long (dry), slender (up to $0.3 \mathrm{~mm}$ ), decurrent, crowded, subulate, long remaining yellowish brown, finally purplish brown. Context dingy whitish in the pileus and the top of the stipe, vinescent, brownish-marbled with age, grey-green in the base of the stipe. Greenish mycelium from the base of the stipe staining dingy pinkish brown to reddish brown in $\mathrm{KOH}$ solution. Odour of water-melon (Citrullus vulgaris) when cut fresh" (Fig. 12).

Due to its bitter taste it is not edible.

\subsubsection{Phytochemistry of Sarcodon scabrosus}

An analysis of the literature revealed that Sarcodon scabrosus (syn Hydnum scabrosus), together with S. imbricatus, is one of the most studied species among Sarcodon. Two classes of secondary metabolites have been isolated from this species, and both are represented by cythane diterpenes: scabronines and sarcodonins. The use of the same name for different classes of secondary metabolites clearly shows how the use of common names can give rise to mistakes.

The first report about the isolation of cyathane diterpenes from S. scabrosus was by Shibata et al. (1989) and it is about sarcodonin A (21) and G (22) (Fig. 13). 


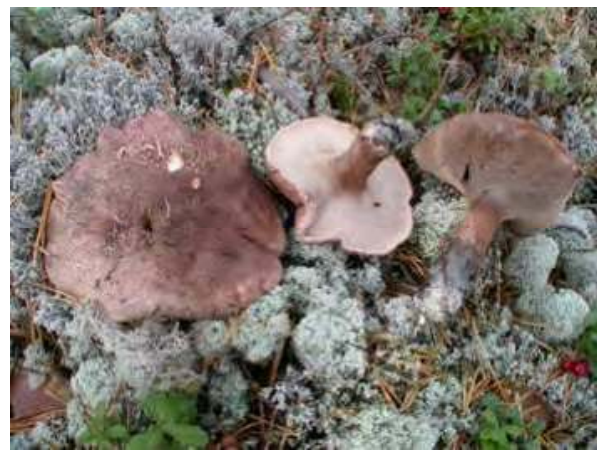

Fig. 12. Sarcodon scabrosus (Fr.) P. Karst.

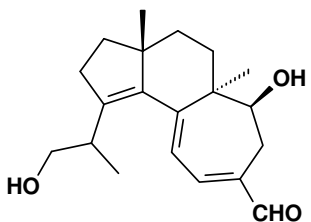

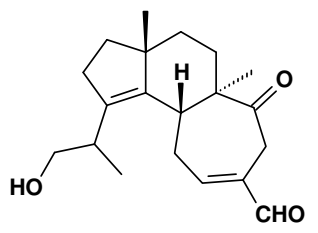

22

Fig. 13. Sarcodonins A and G

Generally sarcodonins and neosarcodonins isolated from S. scabrosus are characterized by the presence of a hydroxyl-methyl group in C-19 (Kryczkowski et al., 2008).

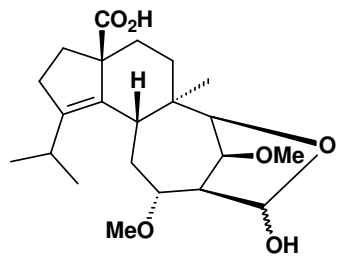

23

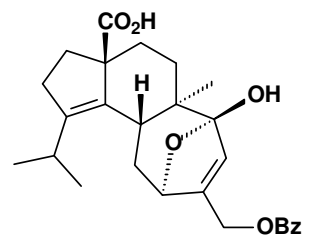

26

Fig. 14. Isolated scabronines

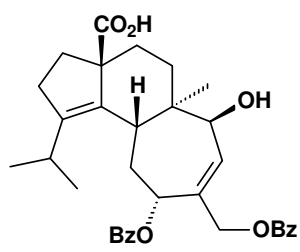

24

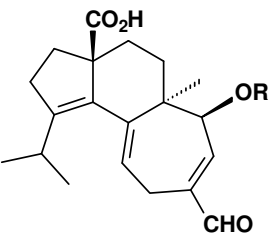

$27 \mathrm{R}=\mathrm{Ac}$

$28 \mathrm{R}=\mathrm{H}$

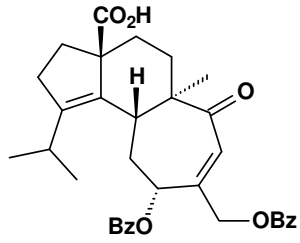

25<smiles>CC(=O)c1ccccc1</smiles> 
Scabronines are characterized by the oxidation of C-17 to carboxylic group. The first scabronine that was isolated was scabronine A (23) (Ohta et al., 1998a) and later scabronines B-F (24-28) were isolated (Kita et al., 1998) (Fig. 14).

Among different cyathane diterpenes, the most interesting for its biological properties is scabronine G (29) (Fig. 15), that has been isolated in 1998 (Ohta et al., 1998b). In 2004, Ma and coworkers reported the isolation of another scabronine $G(\mathbf{3 0})$, but this compound is structurally related to sarcodonins (Ma et al., 2004).

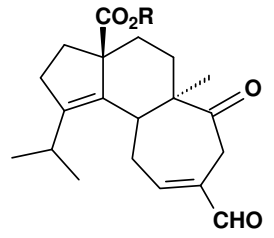

$29 \mathrm{R}=\mathrm{H}$ $31 \mathrm{R}=\mathrm{Me}$

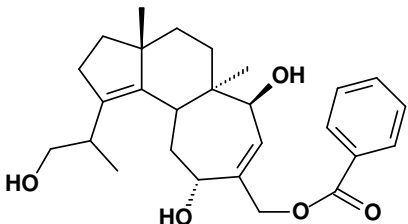

30

Fig. 15. Structures of the two scabronines G

Ma et al. isolated other scabronines (H-J), but they still have sarcodonins structures (Ma et al., 2004; Ma et al., 2008).

From S. scabrosus in addition to the already mentioned sarcodonins A (21) and G (22) in 2002 other three cyathane diterpenoids have been isolated (Hirota et al., 2002). Three of them were named neosarcodonins A-C (31-33). The same group in 2004 isolated neosarcodonin O (34) and three acyl derivatives of sarcodonin A (35-37) (Kamo et al., 2004) (Fig. 16).<smiles>CO[C@H]1C(C=O)=CCC2C3=C(C(C)CO)CC[C@]3(C)CC[C@]2(C)[C@H]1O</smiles>

31

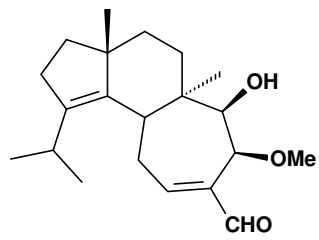

34

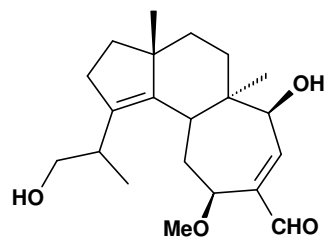

32

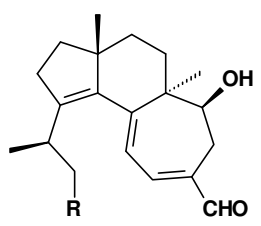

$35 \mathrm{R}=0$-linoleil

$36=0$-oleil

$37=0$-stearil

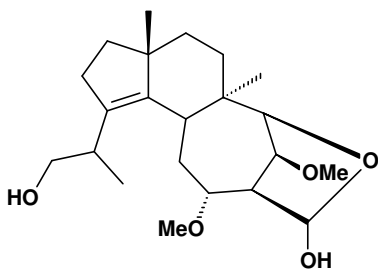

33

Fig. 16. Neosarcodonins isolated from S. scabrosus 


\section{Biological activities of Sarcodon metabolites}

\subsection{Biological activities of p-terphenyl derivatives}

Terphenyls are aromatic hydrocarbons consisting of a chain of three benzene rings. From a structural point of view three different isomers are possible, in which the terminal rings are ortho-, meta-, or para-substituents of the central ring. Most of the natural terphenyls are $p$ terphenyl derivatives. In recent years, some terphenyls have been reported to exhibit significant biological activity, e.g., potent immunosuppressant, neuroprotective, antithrombotic, anticoagulant, specific 5-lipoxygenase inhibitory, and cytotoxic activities (Liu, 2007).

\subsubsection{Antibiotic properties}

Compounds 10 and 11 (Tringali et al., 1987) were tested against several Gram-positive and Gram-negative bacteria in an agar dilution test and the results showed that among Grampositive the most susceptible microorganism was Proteus mirabilis and among Gramnegative Staphylococcus aureus (MIC 75 and $50 \mu \mathrm{g} / \mathrm{ml}$ respectively).

\subsubsection{Antitumoral activity}

Sarcodonin (12) was tested against two different tumor cell lines and it resulted moderately active toward $\mathrm{KB}\left(\mathrm{ED}_{50} 10.0 \mu \mathrm{g} / \mathrm{ml}\right)$ and P-388 (ED $\left.\mathrm{ED}_{50} 27.0 \mu \mathrm{g} / \mathrm{ml}\right)($ Geraci et al., 2000). The higher cytotoxic activity of $\mathbf{1 0}$ with respect to $\mathbf{1 2}$, coupled with mild antibacterial activity already described (Tringali et al., 1987) suggest that $\mathbf{1 0}$ could play a role in the chemical defense of the mushroom.

Compounds 12, 13 (sarcodonin $\alpha$ ), 15 (sarcodonin $\gamma$ ), and 17 (episarcodonin) and the mixture of 19 and 20 (sarcoviolins) were tested in the three-cell line panel High Throughput PreScreen (one-dose primary anticancer assay) carried out at National Cancer Institute (Bethesda, USA). Fully aromatic terphenyls proved to be cytotoxic at a concentration of 5 x10-5 M against NCI-H460 (Lung), MCF7 (Breast), and SF-268 (CNS) cell lines. In particular, 12, 15, and 16 show the highest cytotoxicity towards SF-268 cells, with 96, 93, and 95\% of cells killed, respectively. Sarcoviolins (19 and 20) significantly reduced the growth of all cell lines at $10^{-4} \mathrm{M}$ (MCF7 totally blocked).

\subsection{Biological activities of cyathane diterpenoids}

In 1965 Brodie discovered a new bird's nest fungus of the genus Cyathus that was named C. helenae (Brodie, 1966) and he showed that the metabolites of the mushroom (cyathine complex) possessed antibiotic activity (Allbutt et al., 1971). From this first report, in these 40 years, a great number of cyathane diterpenoids have been isolated, structurally identified and tested for their biological activities.

\subsubsection{Antibiotic activity}

In 1998 Shibata (Shibata et al., 1998) and coworkers isolated from S. scabrosus sarcodonins L and $M$ and sarcodonin A (21) and G (22). Sarcodonin L and M resulted to be identical to scabronines C (25) and B (24), respectively (Kita etal., 1998). All these compounds were tested against $B$. subtilis and $S$. aureus and the results are reported in Table 1. 


\begin{tabular}{|c|c|c|c|c|c|c}
\hline \multirow{2}{*}{ Compound } & \multicolumn{3}{|c|}{ B. subtilis } & \multicolumn{3}{c}{ S. aureus } \\
\cline { 2 - 7 } & $1.0 \%^{*}$ & $0.2 \%$ & $0.05 \%$ & $1.0 \%$ & $0.2 \%$ & $0.05 \%$ \\
\hline $\mathbf{2 1}$ & $6.5^{\star *}$ & & & 7.0 & & \\
\hline $\mathbf{2 2}$ & 6.5 & & & 7.5 & 6.5 & \\
\hline $\mathbf{2 4}$ & 14.0 & 11.0 & 8.0 & 22.0 & 15.0 & 9.0 \\
\hline $\mathbf{2 5}$ & 9.5 & 7.5 & 7.0 & 18.0 & 12.0 & 7.5 \\
\hline
\end{tabular}

*Disc were soaked in $35 \mu \mathrm{l}$ of each test sample (w/v\%); ** The diameter of the inhibitory zone was measured in $\mathrm{mm}$.

Table 1. Antibiotic activity of sarcodonins A, G, L and M

\subsubsection{Anti-inflammatory activity}

Anti-inflammatory activity has been tested for sarcodonin A (21), sarcodonin G (22), neosarcodonin A-C (31-33) (Hirota et al., 2002), neosarcodonin $\mathrm{O}$ (34), acyl derivatives of sarcodonin A (35-37) (Kamo et al., 2004) and glaucopines A-C (5-7) (Curini et al., 2005; Marcotullio et al., 2006a). The results are reported in Table 2. The topical anti-inflammatory activity of compounds was evaluated observing the reduction of oedema induced by TPA, for sarcodonins and neosarcodonins, and Croton oil, for glaucopines, in mouse ear. Indomethacin was used as positive control in all tests.

\begin{tabular}{|c|c|c|c}
\hline Compound & Dose & Animals & \% Oedema Reduction \\
\hline $\mathbf{5}$ & $1.0^{\mathrm{a}}$ & 10 & 62 \\
\hline $\mathbf{6}$ & $1.0^{\mathrm{a}}$ & 10 & 55 \\
\hline $\mathbf{7}$ & $1.0^{\mathrm{a}}$ & 6 & 39 \\
\hline Indomethacin & $0.3^{\mathrm{a}}$ & 10 & 66 \\
\hline $\mathbf{2 1}$ & $0.63^{\mathrm{b}}$ & 5 & 75 \\
\hline $\mathbf{2 2}$ & $0.63^{\mathrm{b}}$ & 5 & 84 \\
\hline $\mathbf{3 1}$ & $0.57^{\mathrm{b}}$ & 5 & 49 \\
\hline $\mathbf{3 2}$ & $0.57^{\mathrm{b}}$ & 5 & 64 \\
\hline $\mathbf{3 3}$ & $0.53^{\mathrm{b}}$ & 5 & 36 \\
\hline $\mathbf{3 4}$ & $0.63^{\mathrm{b}}$ & 5 & 61 \\
\hline $\mathbf{3 5}$ & $0.63^{\mathrm{b}}$ & 5 & 46 \\
\hline $\mathbf{3 6}$ & $0.63^{\mathrm{b}}$ & 5 & 72 \\
\hline Indomethacin & $0.63^{\mathrm{b}}$ & 5 & 16 \\
\hline
\end{tabular}

a Dose $=\mu$ Moles $/ \mathrm{cm}^{2}$; bose $=\mu \mathrm{mol}$

Table 2. Anti-inflammatory activity of sarcodonins, neosarcodonins and glaucopines

\subsubsection{Antiproliferative and antitumoral activities}

The first report about the antitumor activity of a cyathane diterpene was about sarcodonin G isolated from the dichloromethane extract of Sarcolon scabrosus Karst, on HeLa cells in vitro. Sarcodonin G (22), isolated from the mushroom Sarcodon scabrosus and already reported to have anti-inflammatory activity, inhibited proliferation of HeLa cells (Dong et al., 2009). 


\subsubsection{Stimulation of NGF (Nerve Growth Factor)}

Sarcodon scabrosus and S. cyrneus metabolites have been studied for their unique activity to act as neuroprotective agents being able to stimulate the production of neurotrophic factors in vitro. Scabronines A-G (23-29) have been tested for their activity to induce NGF secretion from 1321N1 human astrocytoma cells and induce neuritogenesis in PC12 cells (rat pheochromocytoma cells) (Ohta et al., 1998a, 1998b; Kita et al., 1998; Oshima, Y. et al., 1999). Scabronines increased the expression of mRNA for NGF, and the secretion of NGF from $1321 \mathrm{~N} 1$ cells in a concentration-dependent mechanism (Obara et al., 1999). Among different scabronines, scabronine G methyl ester (SG-ME) (31) resulted to be the most active and the mechanism of action was deeply studied. SG-ME activates PKC- $\zeta$, induces the translocation NF-kB to nucleus and enhances its transcriptional activity (Fig. 17) (Obara et al., 2001).

Cyrneine A-D (1-4) and glaucopine C (7) were tested to evaluate their activity to induce NGF production from 1321N1 cells, but they resulted much less active than scabronine G (Fig. 18) (Marcotullio et al., 2007). Neverthless, cyrneine A and B showed an interesting activity, being able to induce directly differentiation on PC-12 cells (Marcotullio et al., 2006b).

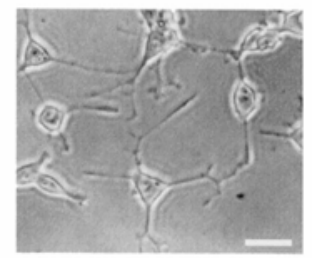

NGF

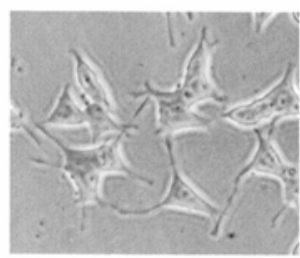

Scabronine G

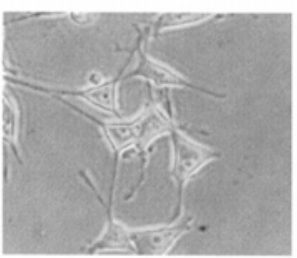

Scabronine G-ME

Fig. 17. Morphological changes of PC-12 cells by the $1321 \mathrm{~N} 1$ cell culture medium conditioned by scabronines. NGF used as control.

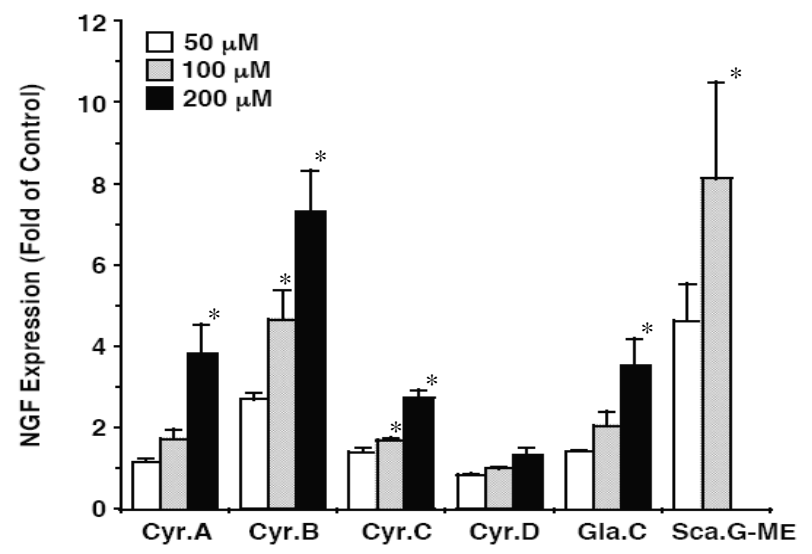

Fig. 18. Evaluation of NGF synthesis from 1321N1 induced by cyrneines and glaucopine C. SG-ME used as control. 
As a transcriptional regulation is required for neurite extension, and the activity of three major transcription factors (activator protein-1 (AP-1), nuclear factor- $\mathrm{KB}$, and $\mathrm{CREB}$ ) was determined. Cyrneines A and B enhanced activation of AP-1 and NF-kB. Moreover, treatment with cyrneine A led to actin translocation and subsequently, to accumulation of Factin at the tip of neurites. Rac1 activity was increased by cyrneine A and expression of a dominant-negative Rac1 mutant significantly inhibited the cyrneine A-induced extension of neurites. These results suggest that cyrneine A induces neurite outgrowth in a Rac1dependent mechanism (Obara et al., 2007).

\section{Conclusions}

The analysis of the literature about Sarcodon genus showed that these mushrooms produces interesting biologically active secondary metabolites such as cyathane e triphenyl derivatives. It is interesting to note that the use of trivial names instead of systematic ones generated some confusion (e.g. the term sarcodonins has been used to name both terphenyls and cyathanes). Furthermore, it was evidenced that sometimes there are problems in the use of different synonyms for the same species. Neverthless, the interesting biological properties of Sarcodon metabolites and the nutritional value of some spp make this genus worthy of further investigations.

\section{References}

Allbutt, A.D.; Ayer, W.A., Brodie, H.J.; Johri, B.N. \& Taube, H. (1971). Cyathin, a new antibiotic complex produced by Cyathus helenae. Canadian Journal of Microbiology, Vol. 17, pp.1401-1407, ISSN 0008-4166

Banker, H.J. (1913). Type Studies in the Hydnaceae III. The Genus Sarcodon. Mycologia Vol.5, No.1, (January 1913), pp. 12-17, ISSN 00275514

Barros, L.; Baptista, P.; Correia, D.M.; Casal, S.; Oliveira, B. \& Ferreira, I.C.F.R. (2007a). Fatty acid and sugar compositions, and nutritional value of five wild edible mushrooms from Northest Portugual. Food Chemistry, Vol. 105, No. 1, pp. 140-145, ISSN 03088146

Barros, L.; Ferreira, M.-J.; Queiros, B.; Ferreira, I.C.F.R. \& Baptista, P. (2007b). Total phenols, ascorbic acid, $\beta$-carotene and lycopene in Portuguese wild edible mushrooms and their antioxidant activities. Food Chemistry, Vol. 103, No. 2, pp. 413-419, ISSN 03088146

Barros, L.; Baptista, P.; Correia, D.M.; Morais, J.S. \& Ferreira I.C.F.R. (2007c). Effects of conservation treatment and cooking on the chemical composition and antioxidant activity of Portuguese wild edible mushrooms. Journal of Agricultural and Food Chemistry, Vol. 55, No. 12, pp. 4781-4788, ISSN 0021-8561

Brodie, H.J. (1966). A new species of cyathus from the Canadian rockies. Canadian Journal of Botany, Vol. 44, No. 10, pp. 1235-1237, ISSN 0008-4026

Cali, V.; Spatafora, C. \& Tringali, C. (2004). Sarcodonins and sarcoviolins, bioactive polyhydroxy-p-terphenyl pyrazinediol dioxide conjugates from fruiting bodies of the basidiomycete Sarcodon leucopus. European Journal of Organic Chemistry, No. 3, pp. 592-599, ISSN 1434-193X

Curini, M.; Maltese, F.; Marcotullio, M.C.; Menghini, L.; Pagiotti, R.; Rosati, O.; Altinier, G. \& Tubaro, A. (2005). Glaucopines A and B, new cyathane diterpenes from the fruiting 
bodies of Sarcodon glaucopus. Planta Medica, Vol. 71, No. 2, pp. 194-196, ISSN 00320943

Dong, M.; Chen, S.-P.; Kita, K.; Ichimura, Y.; Guo, W.-Z.; Lu, S.; Sugaya, S.; Hiwasa, T.; Takiguchi, M.; Mori, N.; Kashima, A.; Morimura, K.; Hirota, M. \& Suzuki, N. (2009). Anti-proliferative and apoptosis-inducible activity of Sarcodonin G from Sarcodon scabrosus in HeLa cells. International Journal of Oncology, Vol.34, No. 1, pp. 201-207, ISSN 1019-6439

Geraci, C.; Neri, P.; Palermo, C.; Rocco, C. \& Trincali, C. (2000). An unusual nitrogenous derivative from the fruiting bodies of the basidiomycete Sarcodon leucopus. Journal of Natural Products, Vol. 63, No. 3, pp. 347-351, ISSN 0163-3864

Han, X.-Q.; Chai, X.-Y.; Jia, Y.-M.; Han, C.-X. \& Tu, P.-F. (2010). Structure elucidation and immunological activity of a novel polysaccharide from the fruit bodies of an edible mushroom, Sarcodon aspratus (Berk.) S. Ito. International Journal of Biological Macromolecules, Vol. 47, No. 3, pp. 420-424, ISSN 0141-8130

Han, X.-Q.; Wu, X.-M.; Chai, X.-Y.; Chen, D.; Dai, H.; Dong, H.-L.; Ma, Z.-Z.; Gao, X.-M. \& $\mathrm{Tu}$, P.-F (2011). Isolation, characterization and immunological activity of a polysaccharide from the fruit bodies of an edile mushroom, Sarcodon aspratus (Berk.) S. Ito. Food Research International, Vol. 44, No. 1, pp.489-493, ISSN 0963-9969

Hirota, M.; Morimura, K. \& Shibata, H. (2002). Anti-inflammatory compounds from the bitter mushroom, Sarcodon scabrosus. Bioscience, Biotechnology, and Biochemistry, Vol. 66, No. 1, pp. 179-184, ISSN 0916-8451

Huang, Y.; Dong, Z. \& Liu, J. (2002). Chemical constituents from the basidiocarp of Sarcodon aspratum. Yunnan Zhiwu Yanjiu, Vol. 24, No. 1, pp. 125-128, ISSN 0253-2700

Hwang, G.J. \& Na, J.H. (2009a). Method for manufacturing porridge comprising Sarcodon aspratus. Patent, KR 2009059262 A 20090611

Hwang, G.J. \& Na, J.H. (2009b) Method for manufacturing flour foods with rich nutrients. Patent, KR 2009059239 A 20090611

Jang, N.S. (2008). Method for manufacturing health beverage from Sarcodon aspratus. Patent, KR 859324 B1 20080919

Kamo, T.; Imura, Y.; Hgio, T.; Makabe, H.; Shibata, H. \& Hirota, M. (2004). Antiinflammatory cyathane diterpenoids from Sarcodon scabrosus. Bioscience, Biotechnology, and Biochemistry, Vol. 68, No. 6, pp. 1362-1365, ISSN 0916-8451

Kim, B.C.; Kim, H.G.; Shin, H.G.; Choi, Y.M. \& Lee, S.H. (2008). Method for softening beef by using Sarcodon aspratus extract. Patent, KR 2008098764 A 20081112

Kim, B.C.; Kim, H.G.; Shin, H.G. \& Choi, Y.M. (2009). Method for manufacturing tenderizer containing Sarcodon aspratus extract and kiwi. Patent, KR 2009013491 A 20090205

Kim, J.K. (2007). Method for preparing alcoholic drink from Sarcodon aspratus, and alcoholic drink prepared by the same capable of maintaining flavour and medicinal efficacy of Sarcodon aspratus for long period of time. Patent, KR 2007026950 A 20070309

Kim, S.K. (2006). Method for making seasoned pork ribs by using Sarcodon aspratus and Acanthopanax senticosus broth for aging pork ribs. Patent, KR 2006128485 A 20061214

Kirk, P.M.; Cannon, P.F.; Minter, D.W. \& Stalpers, J.A. (2008). Dictionary of the Fungi. (10th ed.), CABI, ISBN 0-85199-826-7, Wallingford.

Kita, T.; Takaya, Y.; Oshima, Y.; Ohta, T., Aizawa, K.; Hirano, T. \& Inakuma, T. (1998). Scabronines B, C, D, E, F, novel diterpenoids showing stimulating activity of nerve 
growth factor-synthesis, from the mushroom Sarcodon scabrosus. Tetrahedron, Vol. 54, No. 39, pp. 11877-11886, ISSN 0040-4020

Kobori, M.; Yoshida, M.; Ohnishi-Kameyama, M.; Takei, T. \& Shinmoto, H. (2006) $5 \alpha, 8 \alpha-$ Epidioxy-22E-ergosta-6,9(11),22-trien-3 $\beta$-ol from edible mushroom suppresses growth of HL60 leukemia and HT29 colon adenocarcinoma cells. Biological $\mathcal{E}$ Pharmaceutical Bullettin, Vol. 29, No. 4, pp. 755-759, ISSN 0918-6158

Kobori, M.; Yoshida, M.; Ohnishi-Kameyama, M.; Shinmoto, H. (2007) Ergosterol peroxide from an edible mushroom suppresses inflammatory responses in RAW264.7 macrophages and growth of HT29 colon adenocarcinoma cells. British Journal of Pharmacology, Vol. 150, No. 2, pp. 209-219, ISSN 0007-1188

Kryczkowski, W.; Malinowska, E. \& Herold, F. (2008). The structure, medicinal properties and biosynthesis of cyathane diterpenoids. Biotechnologia, Vol. 80, pp. 146-167, and references cited therein.

Lin, D.W.; Masuda, T.; Biskup, M.B.; Nelson, J.D. \& Baran, P.S. (2011). Synthesis-guided structure revision of the sarcodonin, sarcoviolin, and hydnellin natural product family. Journal of Organic Chemistry, Vol. 76, No. 4, pp. 1013-1030, ISSN 0022-3263

Liu, J.-K. (2007). Secondary metabolites from higher fungi in China and their biological activity. Drug Discoveries \& Therapeutics, Vol. 1, No. 2, pp.94-103, ISSN 1881-7831

Ma, B.-J.; Zhu, H.J. \& Liu, J.-K. (2004) Isolation and characterization of new bitter diterpenoids from the basidiomycete Sarcodon scabrosus. Helvetica Chimica Acta,Vol. 87, pp. 2877-2881, ISSN 0018-019X

Ma, B.-J.; Hu, Q. \& Liu, J.-K. (2006). A new terphenyl derivative from fruitine bodies of the basidiomycete Sarcodon laevigatum. Journal of Basic Microbiology, Vol. 46, No. 3, pp. 239-242, ISSN 0233-111X

Ma, B.-J. \& Ruan, Y. (2008). Scabronine J, a new cyathane-type diterpenoid from the basidiomycete Sarcodon scabrosus. Journal of Antibiotics, Vol. 61, No. 12, pp. 86-88, ISSN 0021-8820

Ma, B.-J. (2009). Method for preparing p-terphenyl compound B1-V. Patent, CN 101423506 A 20090506

Marcotullio, M.C.; Pagiotti, R.; Campagna, V.; Maltese, F.; Fardella, G.; Altinier, G. \& Tubaro, A. (2006a). Glaucopine C, a new diterpene from diterpene from the fruiting bodies of Sarcodon glaucopus. Natural Product Research, Vol. 20, No. 10, pp. 917-921, ISSN 1478-6419

Marcotullio, M.C.; Pagiotti, R.; Maltese, F.; Obara, Y.; Hoshino, T.; Nakahata, N. \& Curini, M. (2006b). Neurite outgrowth activity of cyathane diterpenes from Sarcodon cyrneus, cyrneines A and B. Planta Medica, Vol. 72, No. 9, pp. 819-823, ISSN 00320943

Marcotullio, M.C.; Pagiotti, R.; Maltese, F.; Oball-Mond Mwankie, G.N.; Hoshino, T.; Obara, Y. \& Nakahata, N. (2007). Cyathane diterpenes from Sarcodon cyrneus and evaluation of their activities of neuritogenesis and nerve growth factor production. Bioorganic \& Medicinal Chemistry, Vol. 15, No. 8, pp. 2878-2882, ISSN 0968-0896

Marcotullio, M.C.; Oball-Mond Mwankie, G.N.; Cossignani, L.; Tirillini, B. \& Pagiotti, R. (2008). Phytochemical analysis and antiradical properties of Sarcodon imbricatus (L.:Fr) Karsten. Natural Product Communications, Vol. 3, No. 11, pp. 1907-1910, ISSN 1934-578X 
Maruyama, H.; Yamazaki, K.; Murofushi, S.; Konda, C. \& Ikekawa, T. Antitumor activity of Sarcodon aspratus (Berk.) S. Ito and Ganoderma lucidum (Fr.) Karst. Journal of pharmacobio-dynamics, Vol. 12, No. 2, pp. 118-123 ISSN 0386-846X

Obara, Y.; Hoshino, T.; Marcotullio, M.C.; Pagiotti, R. \& Nakahata, N. (2007). A novel cyathane diterpene, cyrneine $\mathrm{A}$, induces neurite outgrowth in a Rac1-dependent mechanism in PC12 cells. Life Sciences, Vol. 80, No. 18, pp. 1669-1677, ISSN 00243205

Obara, Y.; Kobayashi, H.; Ohta, T.; Ohizumi, Y. \& Nakahata, N. (2001). Scabronine G-methyl ester enhances secretion of neurotrophic factors mediated by an activation of

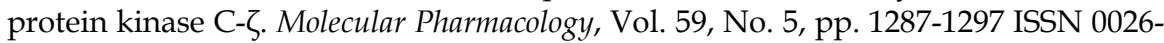
895X

Obara, Y.; Nakahata, N.; Kita, T.; Takaya, Y.; Kobayashi, H.; Hosoi, S.; Kiuchi, F.; Ohta, T.; Oshima, Y. \& Ohizumi, Y. (1999). Stimulation of neurotrophic factor secretion from $1321 \mathrm{~N} 1$ human astrocytoma cells by novel diterpenoids, scabronines A and G. European Journal of Pharmacology, Vol. 370, No. 1, pp. 79-84, ISSN 0014-2999

Ohta, T.; Kita, T.; Kobayashi, N.; Obara, Y.; Nakahata, N.; Ohizumi, Y.; Takaya, Y. \& Oshima, Y. (1998a). Scabronine A, a novel diterpenoid having potent inductive activity of the nerve growth factor synthesis, isolated from the mushroom Sarcodon scabrosus. Tetrahedron Letters, Vol. 39, No. 34, pp. 6229-6232, ISSN 0040-4039

Ohta, T.; Kobayashi, H.; Hosoi, S.; Kiuchi, F.; Kita, T.; Takaya, Y.; Oshima, Y.; Obara, Y.; Nakahata, N. \& Ohizumei, Y. (1999) Stereostructures for diterpenoids having inductive activity on the nerve growth factor synthesis, from Sarcodon scabrosus. Tennen Yuki Kagobutsu Toronkai Koen Yoshishu, Vol. 40, pp. 341-346.

Oshima, Y.; Ohta, Tomihisa, Aisawa, K.; Hirano, T. \& Inakuma, H. (1999). Cyathane derivatives and their use as nervous growth factor(NGF)-formation inducer. Patent, JP 11269125 A 19991005

Shibata, H.; Tokunaga, T.; Karasawa, D.; Hirota, A.; Nakayama, M.; Nozaki, H. \& Tada, T. (1989). Studies on chemical components of mushrooms. Part I. Isolation and characterization of new bitter diterpenoids from fungus Sarcodon scabrosus. Agricultural and Biological Chemistry, Vol. 53, No. 12, pp. 3373-3375, ISSN 0002-1369

Shibata, H.; Irie, A. \& Morita, Y. (1998). Studies on components of mushrooms. IX. New antibacterial diterpenoids from Sarcodon scabrosus fungus. Bioscience, Biotechnology, and Biochemistry, Vol. 62, No. 12, pp. 2450-2452, ISSN 0916-8451

Takei, T.; Yoshida, M.; Ohnishi-Kameyama, M. \& Kobori, M. (2005) Ergosterol peroxide, an apoptosis-inducing component isolated from Sarcodon aspratus (Berk.) S. Ito. Bioscienc,e Biotechnology and Biochemistry, Vol. 69, No. 1, pp. 212-215, ISSN 0916-8451

Tringali, C.; Piattelli, M.; Geraci, C.; Nicolosi, G. \& Rocco, C. (1987). Previously unreported p-terphenyl derivatives with antibiotic properties from the fruiting bodies of Sarcodon leucopus (Basidiomycetes). A two-dimensional nuclear magnetic resonance. Canadian Journal of Chemistry, Vol. 65, No. 10, pp. 2369-2372, ISSN 00084042

Ueno, T.; Yaoita, Y.; Kakuda, R., Machida, K. \& Kikuchi, M. (1999). Studies on the constituents of mushrooms. VII. On the sterol constituents from the fruit bodies of Sarcodon aspratus. Journal of Tohoku Pharmaceutical University, Vol. 46, pp. 71-76, ISSN 1345-157X 
Wang, Z. \& Wang, W. (2008). Tonic alcoholic liquor containing ingredients of precious mushrooms and its preparation method. Patent, CN 101113399 A 20080130

Yaoita, Y.; Kohata, R.; Kakuda, R.; Machida, K. \& Kikuchi M. Ceramide constituents from five mushrooms. Chemical \& Pharmaceutical Bullettin, Vol. 2002, No. 5, pp. 681-684, ISSN 0009-2363

Yorou, N.S. \& Agerer, R. (2007). Tomentella furcata, a new species from Benin (West Africa) with basidia forming internal hyphae. Mycological Progress Vol. 6, No.4, (August 2007), pp. 239 - 247, ISSN 1617-416X 


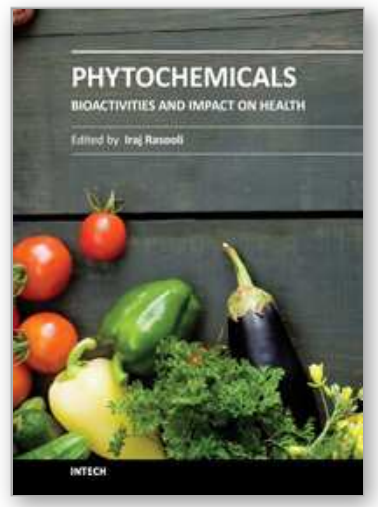

\author{
Phytochemicals - Bioactivities and Impact on Health \\ Edited by Prof. Iraj Rasooli
}

ISBN 978-953-307-424-5

Hard cover, 388 pages

Publisher InTech

Published online 22, December, 2011

Published in print edition December, 2011

Among the thousands of naturally occurring constituents so far identified in plants and exhibiting a long history of safe use, there are none that pose - or reasonably might be expected to pose - a significant risk to human health at current low levels of intake when used as flavoring substances. Due to their natural origin, environmental and genetic factors will influence the chemical composition of the plant essential oils. Factors such as species and subspecies, geographical location, harvest time, plant part used and method of isolation all affect chemical composition of the crude material separated from the plant. The screening of plant extracts and natural products for antioxidative and antimicrobial activity has revealed the potential of higher plants as a source of new agents, to serve the processing of natural products.

\title{
How to reference
}

In order to correctly reference this scholarly work, feel free to copy and paste the following:

Maria Carla Marcotullio (2011). Sarcodon Mushrooms: Biologically Active Metabolites, Phytochemicals Bioactivities and Impact on Health, Prof. Iraj Rasooli (Ed.), ISBN: 978-953-307-424-5, InTech, Available from: http://www.intechopen.com/books/phytochemicals-bioactivities-and-impact-on-health/sarcodon-mushroomsbiologically-active-metabolites

\section{INTECH}

open science | open minds

\section{InTech Europe}

University Campus STeP Ri

Slavka Krautzeka 83/A

51000 Rijeka, Croatia

Phone: +385 (51) 770447

Fax: +385 (51) 686166

www.intechopen.com

\section{InTech China}

Unit 405, Office Block, Hotel Equatorial Shanghai

No.65, Yan An Road (West), Shanghai, 200040, China 中国上海市延安西路65号上海国际贵都大饭店办公楼 405 单元

Phone: +86-21-62489820

Fax: +86-21-62489821 
(C) 2011 The Author(s). Licensee IntechOpen. This is an open access article distributed under the terms of the Creative Commons Attribution 3.0 License, which permits unrestricted use, distribution, and reproduction in any medium, provided the original work is properly cited. 